\title{
DAYA HAMBAT EKSTRAK DAUN KARI TERHADAP PERTUMBUHAN BAKTERI Staphylococcus aureus
}

\author{
Lisna Unita, Colvin Voon \\ Department of Biology Oral Faculty of Dentistry University of Sumatera Utara
}

\begin{abstract}
Curry leaves ( Murraya koenigii ) can be used as a spice in cooking and curry leaf extract, has the effect of antimicrobial activity can inhibit the growth of Staphylococcus aureus. The purpose of this study was to determine the curry leaf extract solution of various concentrations to inhibit the growth of Staphylococcus aureus and know the difference inhibition curry leaf extract solution between the various different concentrations on the growth of Staphylococcus aureus. This study uses laboratory Experimental design by Design Posttest only control group design. Test method using agar diffusion techniques and media used are media Mueller Hinton Agar ( MHA) containing Staphylococcus aureus. After incubation for 24 hours and then measure the inhibition zone which formed. One Way Anova Test results obtained curry leaf extract solutions were made in different concentrations of $2.5 \%, 5 \%, 7.5 \%$ and $10 \%$ can inhibit the growth of Staphylococcus aureus. The higher concentration of curry leaf extract greater inhibitory power and show stronger antibacterial activity. Multiple Comparison Test Results ( LSD ) significant difference $(p<0.05)$ between the inhibition of curry leaf extract $2.5 \%$ to $10 \%$, with a value of $p=0.002$, and curry leaf extract 5 $\%$ to $10 \%$ with the value of $p=0.007$.
\end{abstract}

Keywords : curry leaves, staphylococcus aureus

\section{PENDAHULUAN}

Pengobatan herbal merupakan suatu cara alternatif bersifat tradisional, dari zaman dahulu, seluruh dunia menggunakan tananman obat sebagai herbal. Sekitar $80 \%$ dari 4000 juta penduduk dari bumi ini menggunakan obat herbal bagi perawatan kesehatan. Daun kari (Murraya koenigii) merupakan tanaman yang banyak tumbuh di India, Nepal, Sri lanka, Myanmar, Indonesia, China Selatan, Hainan dan beberapa negara di Asia Selatan. ${ }^{1}$ Daun kari berasal dari daerah Tarai dari Utar Pradesh, India. Dan pada saat itu dibudidayakan di Burma, Ceylon, Cina, Australia dan Kepulauan Pasifik. Tanaman ini tumbuh dengan biji, minyak atisiri, minyak daun kari, yang dihasilkan dari tanaman ini telah digunakan dalam industri pembuatan sabun. ${ }^{2}$ Manfaat tanaman obat ini terdapat pada beberapa zat aktif kimia yang mempengaruhi proses fisiologis tertentu pada tubuh manusia. Bahan aktif pada tanaman yang paling penting adalah alkaloid, tanin, flavonoid dan fenolic. ${ }^{3}$

Ekstrak daun kari mempunyai efek aktivitas antimikroba dan dapat menghambat pertumbuhan Staphylococcus aureus, Pseudomonas aeruginosa dan Candida spesies, Bacillus subtilis, Streptococcus, Staphylococcus aureus, Cornybacterim, S.pyogenes, Mycobacterium tuberculosis. Staphylococcus aureus bersifat sensitif terhadap ekstrak. Akerela dan Ayinde (1998) mengamati bahwa minyak atsiri dari Murraya koeinigii menunjukkan efek penghambatan terhadap Staphylococcus aureus. ${ }^{4,5,6}$
Daun kari (Muraya Koenigiispreng - a green leafy vegetables) tumbuh di seluruh India dan negaranegara lain, dan daun aromatiknya digunakan sebagai masakan India. Daun kari segar mengandung 2,65\% volatile minyak esensial seperti sesquiterpenes dan monoterpenes memiliki efek antimikroba dan juga mengandung klorofil, thymol, minyak kayu putih, mentol dan tepenes, yang memiliki efek aktivitas antibakteri dan antijamur. Semua bahan ini mengandung efek antimikroba yang luas, dan memiliki kemampuan menembus biofilm untuk membunuh microorganisma. ${ }^{4}$ Penelitian Math M.V\&P Balasubramaniam (2004) melaporkan bahwa daun kari terdiri dari karoten, beta karoten, asam folat, riboflavin, zat besi, kalsium dan seng semua bahan ini dapat menjaga kesehatan mulut, dan berpendapat bahwa klorofil dari daun kari adalah agen antikariogenik. Pemeriksaan kimia terhadap minyak dilakukan pada daun dan biji, dan berpendapat bahwa mempunyai aktivitas antibakteri dan antijamur yang kuat. Alkaloid, murrayacinine, adalah juga ditemukan dalam tanaman ini. $6,7,8$,

Minyak esensial dari daun kari ini menunjukkan efek antibakteri terhadap Bacillus subtilis, Staphylococcus aureus, S.pyogens, Proteus vulagris dan Pasteurella multicida. Minyak murninya aktif terhadap tiga pertama organisma bahkan pada pengenceran 1:500. Ekstrak dari aceton daun kari segar Murraya koenigii pada fraksasi memberikan tiga alkaloid carbozole bioaktif disebut sebagai mahanimbine, murrayanol dan mahanine, yang ada efek mosquitocidal, antimikroba dan kegiatan penghambatan topisomerase I dan II. ${ }^{9}$ 
Semua konsentrasi ramuan ekstrak Murraya koenigii menunjukkan penghambatan yang paling efektif terhadap semua bakteri yaitu antara bakteri gram-positif dan bakteri gram negatif yang diuji. Bakteri gram-positif lebih rentan terhadap ekstrak. Hal ini dapat dijelaskan bahwa membran luar bakteri gram negatif dikenal sebagai penghalang bagi penetrasi berbagai molekul antibiotik dan ruang periplasmic mengandung enzim yang mampu mendegradasi molekul eksogen. Ini mungkin karena adanya metabolit sekunder dalam ekstrak. Flavonoid,saponin dan tanin senyawa yang ada dalam Murraya koenigii dikenal sebagai antimikroba properti. Tanin telah ditemukan untuk menghambat sintesis protein dengan bentuk kompleks ireversibel. ${ }^{10}$

Semua jenis ekstrak dari tanaman menunjukkan efek antibakteri bervariasi terhadap semua bakteri pathogen yang menyebabkan penyakit pada manusia dan hewan. Ekstrak etanol menunjukkan hasil terbaik diikuti oleh aseton dan ekstrak air. Ekstrak air menunjukkan aktivitas kurang dari aseton dan etanol ekstrak mungkin karena adanya sejenis zat aktif dalam ekstrak air, dalam konsentrasi rendah atau zat aktif yang larut dalam pelarut organik. Murraya koenigii memberikan zona bening

E.coli dan S. aureus dengan ekstrak yang tersisa gagal menghasilkan zona bening terhadap pathogen ini. Wendakoon et al. (2012) melaporkan bahwa ekstrak etanol aktif terhadap gram positif dan grambakteri negatif. ${ }^{11}$

Akhir-akhir ini ketetarikan akan produk dengan kandungan dasar dari bahan alami telah meningkat karena penggunaan produk natural lebih aman. Berdasarksan uraian tersebut diatas, peneliti tertarik untuk meneliti daya hambat ekstrak daun kari terhadap bakteri Staphylococcus aureus. Hasil penelitian ini diharapkan dapat memberikan informasi yang lebih lanjut mengenai peranan daun kari terhadap kesehatan rongga mulut khususnya dalam pencegahan dan perawatan kesehatan gigi.

\section{BAHAN DAN METODE}

Pembuatan ekstrak daun kari di Laboratorium Fitokimia Fakultas Farmasi, Universitas Sumatera Utara. Setelah dikeringkan kemudian dihaluskan dengan blender, ditimbangkan hasilnya sebanyak $(270 \mathrm{~g})$. Selanjutnya, prosedur pengekstrakan dilakukan dengan cara maserasi dengan etanol 95\%. Setelah 5 hari, melakukan proses penyaring dan seterusnya proses rotary dilakukan dengan pemakaian vacumm rotavapor. Setelah mendapat ekstrak kental daun kari langsung dilakukan mikro uji. Jenis penelitian yang dilakukan adalah rancangan Experimental Laboratoirum dengan Posttest Only Control Group Design yaitu melakukan pengukuran atau observasi sesudah perlakuan diberikan. Populasi penelitian ini adalah bakteri Staphylococcus aureus. Sampel yang diambil adalah Staphylococcus aureus yang diperoleh dari Laboratorium Mirkrobilogi Farmasi USU.

Pembuatan media Nutrient Agar (NA): Sebanyak 23 g nutrient agar (NA) dimasukkkan ke dalam Erlenmeyer tambahkan air suling hinnga 1000 $\mathrm{ml}$, dipanaskan sampai larut. Kemudian disterilkan di dalam autoklaf pada suhu $115^{\circ} \mathrm{C}$ selama 30 menit. Pembuatan media Mueller Hinton Agar (MHA): untuk mendapatkan 5 petri media pembiakan bakteri, Mueller Hinton Agar (MHA) sebanyak 1,9 gram dilarutkan dalam $50 \mathrm{~mL}$ aquadest, panaskan di atas hotplate sambil diaduk hingga mendidih. Kemudian media yang telah masak, dimasukkan di dalam 5 buah tabung reaksi dan disterilkan di dalam autovlave selama 15 menit dengan tekanan udara 2 Atm pada suhu $120^{\circ} \mathrm{C}$. Setelah disterilkan, media disimpan di dalam kulkas. Jika akan digunakan, media dipanaskan kembali hingga mendidih kemudidan dituangkan ke dalam masing-masing petri dan dibiarkan hingga memadat.

Seterusnya melakukan pembuatan agar miring.Tabung reaksi dimasukkan $3 \mathrm{ml}$ media nutrient agar, didiamkan pada suhu kamar sampai sediaan membeku pada posisi miring. Hasil disimpan pada lemari pendingin. Pembuatan stok kultur masingmasing sebanyak satu ose dari biakan murni bakteri Staphylococcus aureus ditanamkan pada media nutrient agar (NA) miring dengan cara menggores, ditutup mulut tabung dengan kapas. Kemudian diinkubasi dalam incubator pada suhu 36 derajat celcius selama 18-24 jam. Selanjutnya, pembuatan ekstrak etanol daun kari dalam berbagai konsentrasi. Daun kari sebanyak 1 $\mathrm{kg}$ dibersihkan terlebih dahulu kemudian dikeringkan selama 24 jam pada suhu kamar. Setelah itu, direndam bersama etanol sebanyak $2,7 \mathrm{~L}$ di dalam botol bertutup berwarna gelap agar terlindung dari sinar matahari selama 24 jam untuk proses pemaserasian. Hasil pemaserasian disaring dengan selapis kertas saring (Whatman no 42, England) dan kemudian di pekatkan dengan alat rotary evaporator pada suhu tidak lebih $50^{\circ} \mathrm{C}$ melalui proses penguapan sehingga terpisah pelarut etanol dengan ekstrak tumbuhan. Ekstrak kental yang diperoleh kemudian dimasukkan ke dalam botol

Untuk mendapatkan konsentrasi ekstrak daun kari sebanyak 2,5\%, 5\%, 7,5\% dan 10\%, masingmasing dilarutkan dalam $100 \mathrm{ml}$ larutan Dimetil Sulfoksida (DMSO) yang merupakan bahan alami dari serat kayu dan tidak berbahaya. DMSO berfungsi sebagai pelarut yang cepat meresap ke dalam epitel ekstrak tanpa merusak sel-sel tersebut dan sering digunakan dalam bidang kedokteran dan kesehatan. Ekstrak etanol daun kari 2,5\% adalah 2,5 gram/100 mL $=0,025 \mathrm{gram} / \mathrm{mL}$ DMSO; $5 \%$ adalah $\quad 5 \mathrm{gram} / 100$ $\mathrm{mL}=0,05 \mathrm{gram} / \mathrm{mL}$ DMSO; 7,5\% gram $/ 100 \mathrm{~mL}=$ $0,075 \mathrm{gram} / \mathrm{mL}$ DMSO dan $10 \%$ adalah $10 \mathrm{gram} / 100$ $\mathrm{mL}=0,1$ gram.100 mL DMSO. Ekstrak yang telah dilarutkan, kemudian dimasukkan kedalam botol vial yang telah steril dan disimpan di dalam kulkas sampai waktu digunakan.

Pembiakan spesimen masing-masing petri dibagi menjadi 5 area, diperlukan 5 petri untuk mendapatkan 25 sampel kelompok perlakuan. Staphylococcus aureus yang digunakan adalah spesimen yang diperoleh dari Laboratorium Mikrobiologi Farmasi USU yang telah dibiakkan secara murni pada Mueller Hinton Agar. Untuk mendapatkan 
sampel dilakukan kembali pembiakan spesimen pada sejumlah piring petri yang berisi Mueller Hinton Agar. Koloni yang sudah diencerkan dalam $\mathrm{NaCl}$ 0,9 \% lalu divortex sampai diperoleh kekeruhan sesuai standart Mc Farland (1x $\left.10^{8} \mathrm{CFU} / \mathrm{ml}\right)$. Lalu disebarkan dengan kapas lidi steril secara zig-zag dan rapat untuk mendapatkan pertumbuhan koloni yang padat pada media. Biarkan selama 1 jam. Uji efektivitas antibakteri metode difusi agar Urutan pengujian efektivitas antibakteri adalah sebagai berikut :

Penetesan bahan coba pada cakram kosong. Diperlukan 5 buah cakram kosong untuk masingmasing bahan coba. Sebanyak 0,1 ml suspensi bahan coba diteteskan pada cakram kosong sesuai dengan kosentrasi 2,5\%, 5,0\%, 7,5\% dan $10 \%$ dengan menggunakan pipet mikro. Setelah ditetesi, dibiarkan selama 60 menit.

Kemudian petri dimasukkan kedalam inkubator dengan suhu $37^{\circ} \mathrm{C}$ dan diamati kembali setelah 24 jam. Diamati zona hambat yang terjadi disekitar masing-masing disk. Kemudian dilakukan pengukuran diameter yang bebas koloni (zona bening) dengan menggunakan kaliper geser (Tricebrand, China) dan kemudian dicatat.

\section{Cara pengukuran zona hambat}

Kemudian dilihat zona hambat/zona bening bakteri Staphylococcus aureus dan diukur disekitarnya mengunakan kaliper. Zona hambat yang terbentuk diukur sebanyak dua kali yaitu pengukuran secara diameter vertikal dan diameter horizontal. Kemudian hasil ditambah dan dibagi dua. Setelah itu dicatat hasilnya.

\section{HASIL}

Pengujian aktivitas antibakteri daun kari (Murraya koenigii) dilakukan terhadap bakteri Staphylococcus aureus secara in vitro menggunakan metode agar diffusion test. Setelah perletakan semua bahan coba yaitu ekstrak daun kari 2,5\%,5\%, 7,5\% dan $10 \%$ dilakukan pengamatan setelah 24 jam untuk melihat zona bening di sekitar cakram. Terbentuknya zona hambat di sekitar koloni bakteri menunjukkan adanya penghambatan pertumbuhan bakteri uji. Zona penghambatan bakteri dinyatakan dalam milimeter (mm) yang diukur dari diameter zona hambat yang terbentuk. Semakin luas zona hambat menunjukkan semakin tinggi aktivitas antibakteri.

Tabel 1. Perbedaan rata-rata zona hambat ekstrak daun kari $2,5 \%, 5 \%, 7,5 \%$ dan $10 \%$

\begin{tabular}{|c|c|c|c|c|}
\hline Kelompok & $\begin{array}{c}\text { Perlakuan } \\
\text { (Murraya } \\
\text { Koenigii) }\end{array}$ & $\mathbf{N}$ & $\mathbf{X} \pm$ SD & P \\
\hline I & $2,5 \%$ & 5 & $9,60 \pm 0,57009$ & \\
II & $5 \%$ & 5 & $9,83 \pm 0,64848$ & \\
III & $7,5 \%$ & 5 & $10,33 \pm 0,54612$ & $0,010^{*}$ \\
IV & $10 \%$ & 5 & $11,09 \pm 0,77653$ & \\
\hline
\end{tabular}

* Signifikans
Tabel 1 menunjukkan hasil Uji Anova one way dapat dilihat bahwa $p$ adalah 0.010 . Hal ini berarti terdapat perbedaan yang bermakna $(\mathrm{p}<0,05)$, diantara ekstrak daun kari 2,5\%, 5\%, 7\% dan 10\%. Untuk mengetahui perbedaan rata-rata zona hambat diantara masing-masing bahan coba dapat dilihat dari uji komparasi ganda (LSD)

Tabel 2. Hasil uji komparasi ganda (LSD)

\begin{tabular}{|c|c|l|}
\hline $\begin{array}{c}\text { Konsentrasi } \\
\text { Murraya } \\
\text { koenigii) }\end{array}$ & $\begin{array}{c}\text { Perbandingan } \\
\text { Konsentrasi }\end{array}$ & $P$ \\
\hline $2,5 \%$ & $5 \%$ & 0.572 \\
& $7,5 \%$ & 0.091 \\
$5 \%$ & $10 \%$ & $0.002^{*}$ \\
& $2,5 \%$ & 0.572 \\
& $7,5 \%$ & 0.239 \\
$7,5 \%$ & $10 \%$ & $0.007 *$ \\
& $2,5 \%$ & 0.091 \\
$10 \%$ & $5 \%$ & 0.239 \\
& $10 \%$ & 0.079 \\
& $2,5 \%$ & $0.002 *$ \\
& $5 \%$ & $0.007 *$ \\
\hline
\end{tabular}

* signifikan

Tabel 2 menunjukkan (uji komparasi ganda), diperoleh ekstrak daun kari dengan konsentrasi 2,5\% terhadap $5 \%$ dan $7,5 \%$ tidak ada perbedaan yang bermakna, ( $>>0,05)$, karena jarak mean antara 2,5\% dan $5 \%$ sangat dekat $(9,60-9,83 \mathrm{~mm})$. Konsentrasi $2,5 \%$ terhadap $7,5 \%$ tidak ada perbedaan yang bermakna, (p>0,05) karena jarak mean antara $2,5 \%$ dan $7,5 \%$ sangat dekat. Sedangkan pada konsentrasi $10 \%$ terdapat perbedaan yang bermakna, $(\mathrm{p}<0,05)$ dengan nilai 0,002 , karena jarak mean antara 2,5\% dengan $10 \%$ lebih jauh. Ekstrak daun kari dengan 5\% terhadap 7,5\% tidak ada perbedaan yang bermakna, $(\mathrm{p}>0,05)$ karena jarak mean antara 5\% dengan 7,5\% lebih dekat, tetapi pada konsentrasi $10 \%$ terdapat perbedaan yang bermakna $(\mathrm{p}<0,05)$ dengan nilai 0,007 , karena jarak mean antara $5 \%$ dengan $10 \%$ lebih jauh. Ekstrak daun kari dengan konsentrasi $7,5 \%$ terhadap $10 \%$ tidak ada perbedaan yang bermakna, $(p>0,05)$ karena jarak mean antara $7,5 \%$ dengan $10 \%$ lebih jauh.

\section{PEMBAHASAN}

Penelitian tentang konsentrasi ekstrak daun kari (Murraya koenigii) adalah untuk membuktikan bahwa daun kari memiliki daya hambat terhadap pertumbuhan Staphylococcus aureus dan melihat perbedaan daya hambat antara beberapa konsentrasi ekstrak daun kari 2,5\%, 5\%, 7,5\% dan 10\%. Metode yang digunakan pada penelitian ini adalah metode agar difusi test. Tujuan penelitian ini adalah untuk mengetahui larutan ekstrak daun kari (Murraya koenigii) yang dibuat dalam berbagai konsetrasi dapat menghambat pertumbuhan Staphylococcus aureus dan mengetahui perbedaan daya hambat antara beberapa 
konsentrasi larutan ekstrak daun kari terhadap pertumbuhan Staphylococcus aureus. Perbedaan daya hambat bahan coba yang diamati pada pada media Mueller Hinton Agar (MHA) yang telah diinokulasi oleh Staphylococcus aureus.

Penelitian ini merupakan penelitian eksperimental yang menggunakan lima kelompok perlakuan yang terdiri atas kelompok 1 (kontrol), kelompok 2 (ekstrak daun kari 2,5\%), kelompok 3 (ekstrak daun kari 5\%), kelompok 4 (ekstrak daun kari $7,5 \%$ ), dan kelompok 5 (ekstrak daun kari 10\%). Masing-masing dari beberapa konsentrasi daun kari yang digunakan dalam penelitian ini dilakukan pengulangan sebanyak lima kali dan semua pengulangan tersebut dilakukan dalam waktu yang bersamaan.

Pengukuran zona hambat dilakukan setelah 24 jam, dengan menggunakan kaliper geser. Zona hambat merupakan daerah dimana terdapat zona bening di sekililing disk yang menunjukkan adanya daya hambat ekstrak daun kari terhadap Staphylococcus aureus. Penelitian ini dimulai dengan pembuatan ekstrak daun kari dibuat secara sederhana dengan menggunakan alat rotary evaporator. Ekstraksi merupakan suatu metode yang sering digunakan untuk mendapat senyawa dari tumbuhan. Pelarut yang digunakan adalah etanol $95 \%$ untuk mendapatkan senyawa yang terdapat dalam tanaman sehingga semua senyawa dapat diekstrak keluar. Pengenceran ekstrak dilakukan dengan larutan dimetil sulfoksida (DMSO). Larutan ini merupakan larutan standar yang digunakan dalam pengenceran ekstrak. DMSO merupakan pelarut alami dari serat kayu yang terdiri dari selulosa dan hemiselulosa berfungsi sebagai pelarut yang cepat meresap ke dalam epitel ekstrak tanpa merusak sel-sel tersebut.

Tabel 1, menunjukkan hasil Uji Anova One way berdasarkan hasil penelitian rata-rata zona hambat ekstrak daun kari2,5\% adalah 9.60 $\pm 0,570 \mathrm{~mm}$, ekstrak daun kari $5 \%$ adalah $9.83 \pm 0.648 \mathrm{~mm}$, ekstrak daun kari $7,5 \%$ adalah $10.33 \pm 0.546 \mathrm{~mm}$ dan $10 \%$ adalah $11.09 \pm 0.776 \mathrm{~mm}$ dan kontrol $(D M S O) 0 \mathrm{~mm}$, dapat dilihat bahwa $\mathrm{p}=0.010$. Hal ini terdapat perbedaan yang bermakna $(\mathrm{p}<0,05)$ diantara ekstrak daun kari $2,5 \%$, $5 \%, 7 \%$ dan $10 \%$.

Tabel 2 menunjukkan (uji komparasi ganda), diperoleh ekstrak daun kari dengan konsentrasi 2,5\% terhadap 5\% tidak ada perbedaan yang bermakna, ( $>0,05$ ), Konsentrasi 2,5\% terhadap 7,5\% tidak ada perbedaan yang bermakna, $(\mathrm{p}>0,05)$. Sedangkan pada konsentrasi $10 \%$ terdapat perbedaan yang bermakna, $(\mathrm{p}<0,05)$ dengan nilai 0,002 . Ekstrak daun kari $5 \%$ terhadap $7,5 \%$ tidak ada perbedaan yang bermakna, $(\mathrm{p}>0,05)$ tetapi pada konsentrasi $10 \%$ terdapat perbedaan yang bermakna $(\mathrm{p}<0,05)$ dengan nilai 0,07 . Ekstrak daun kari dengan konsentrasi $7,5 \%$ terhadap $10 \%$ tidak ada perbedaan yang bermakna, $(p>0,05)$.

Penelitian ini sesuai dengan penelitian Seniyadkk (2011) menggunakan ekstrak daun kari (Murraya koenigii) berbagai konsentrasi dengan pelarut etanol dapat menghambat bakteri Staphylococcus aureus dengan konsentrasi $10 \%$ adalah $11 \mathrm{~mm}, 15 \%$ adalah $13 \mathrm{~mm}$ dan $20 \%$ adalah $16 \mathrm{~mm}$. Penelitian ini menunjukkan bahwa semakin tinggi konsentrasi eksrak daun kari maka aktivitas antibakterinya akan semakin kuat. $^{15}$

Beberapa faktor yang mempengaruhi adanya zona hambat tergantung terhadap kemampuan difusi bahan antimikroba ke dalam media dan interaksinya dengan mikroorganisme yang diuji, jumlah mikroorganisme yang digunakan, kecepatan tumbuh mikroorganisme yang diuji dan sensitivitas mikroorganisme terhadap bahan antimikroba yang diuji.

Penelitian Priya (2014) menyatakan bahwa daun kari (Murraya koenigii) dapat menghambat pertumbuhan Staphylococcus aureus karena mengandung minyak essential. Minyak essential terkandung dalam daun kari diklasifikasikan dalam empat kelompok: Monoterpenes Hydrocarbons (11,81\%), Oxgenated Monoterpenes (72,51\%), Sesquiterpenes Hydrocarbons (3.12\%) dan Oxygenated Sesquiterpenes $(10,48 \%)$. Hasil penelitian Priya dengan konsentrasi ekstrak daun kari $0,005 \%$ menunujukkan rata-rata diameter zona hambat daun kari terhadap Staphylococcus aureus adalah $15 \mathrm{~mm}$. Penelitian Jain (2012) menyatakan bahwa ekstrak minyak essential dari daun kari dan aqueos extract dapat menghambat bakteri Staphyloccoccus aureus, Staphylococcus epidermis dan Streptococcus spesies. ${ }^{14}$

Menurut penelitian Basakaran (2011) menunujukkan bahwa ekstrak daun kari (Murraya koenigii) mempunyai efek antibakteri karena mengandung tanin dan flavonoid. Ekstrak daun kari dengan konsentrasi $0,001 \%$ dengan menggunakan pelarut ciproflaxin menunjukkan rata-rata diameter zona hambat adalah $22.10 \pm 0.17 \mathrm{~mm}$. Tanin berpotensi mempunyai efek antibakteri jika beraksi dengan protein dan dapat menghambat bakteri dengan merusak dinding sel membran dan flavonoid mempunyai efek antiviral. ${ }^{12}$

Penelitian Vohra (2011) menunjukkan bahwa ekstrak daun kari (Murraya koenigii) dengan konsentrasi 0,1\% mempunyai efek antibakteri terhadap bakteri Staphylococcus aureus . Rata-rata diameter zona hambat adalah 20-25 mm. Tanin dan flavonoid adalah bahan aktif yang dapat menghambat bakteri Staphylococcus aureus. Senyawa flavonoid bekerja pada bakteri dengan cara merusak membran sitoplasma. Membran sitoplasma bakteri yang berfungsi mengatur masuknya bahan makanan dan nutrisi, apabila membran sitoplasma rusak maka metabolit penting dalam bakteri akan keluar dan bahan makanan untuk menghasilkan energi tidak dapat masuk sehingga sel bakteri tidak mampu tumbuh dan akhirnya terjadi kematian sel. ${ }^{13}$

Pada penelitian Dwivedi (2012) menyatakan $50 \%$ ekstrak methanol daun kari (Murraya koenigii) mempunyai efek daya hambat terhadap Staphylococcus aureus karena mempunyai bahan aktif seperti alkaloids, tannins, steroids, dan saponins. Dan bahan-bahan aktif seperti ini ada efek antioxidants dan antimicrobial. 
Penelitian menggunakan kosentrasi $0,25 \%$ dan $0,5 \%$ sebagai bahan coba dan rata-rata diameter zona hambat adalah $19 \mathrm{~mm}$ dan $28 \mathrm{~mm} .{ }^{16}$

Hasil Uji Anova one way pada tabel 1 dapat dilihat bahwa $\mathrm{p}$ adalah 0.010 . Hal ini berarti terdapat perbedaan yang bermakna $(\mathrm{p}<0,05)$ diantara ekstrak daun kari 2,5\%, 5\%, 7\% dan 10\%. Dari tabel 2 (Uji Komparasi Ganda) di atas diperoleh bahwa Ekstrak daun kari 2,5\% terhadap $10 \%$ terdapat perbedaan yang bermakna $(\mathrm{p}>0,05)$. Ekstrak daun kari $10 \%$ paling baik daya hambatnya.

Zona bening (zona inhibition) yang ditunjukkan pada ekstrak daun kari (Murraya koenigii), ekstrak $10 \%$ adalah yang paling besar. Setelah waktu pengamatan selama 24 jam menunjukkan bahwa sediaan ekstrak daun kari (Murraya koenigii) bersifat menghambat pertumbuhan bakteri Staphylococcus aureus. Minyak esensial tersebut dan bahan-bahan aktif terkandung dalam daun kari dapat digunakan sebagai bahan alternatif antibakteri karena memiliki daya hambat terhadap berbagai bakteri.

\section{KESIMPULAN}

Berdasarkan hasil penelitian daya hambat ekstrak daun kari terhadap pertumbuhan bakteri Staphylococcus aureus dapat disimpulkan yaitu: Larutan ekstrak daun kari yang dibuat dalam berbagai konsentrasi 2,5\%, 5\%, 7,5\% dan 10\% dapat menghambat pertumbuhan Staphylococcus aureus. Semakin tinggi konsentrasi ekstrak daun kari semakin besar daya hambatnya dan menunjukkan aktivitas antibakterinya semakin kuat. Terdapat perbedaan yang bermakna $(\mathrm{p}<0,05)$ daya hambat antara ekstrak daun kari $2,5 \%$ terhadap $10 \%$, dengan nilai $\mathrm{p}=0.002$, dan ekstrak daun kari $5 \%$ terhadap $10 \%$ dengan nilai $\mathrm{p}=0,007$.

\section{DAFTAR PUSTAKA}

1. Bonde S.D, Nemade L.S, Patel M.R, Patel A.A. Murraya koenigii (Curry leaf): Ethnobotany, Phytochemistry and Pharmacology - A Review. International Journal of Pharmaceutical and Phtopharmacological Research. 2011;1(1):23-7.

2. Parul S, Javed A, Neha B, Honey J, and Anuj B. Curry leaves- A medical herb. School of Pharmaceutical Sciences, Jaipur National University, Jaipur. 2012;2(2):51-3.

3. Shihabudeen M.S, Priscilla Hansi H.D, Thirumurugan K. Antimicrobial activity and phytochemical analysis of selected Indian medicinal plants. International Journal of Pharma Sciences and Research 2010;1(10):430-4.
4. Katoch A, Batta B, Kumar A, Sharma P.C.Screening of murraya koenigii (curry) and camellia sintesis (Tea) leaves for antimicrobial activity against trains of staphylococcus aureus, psedomonas aeruginosa and candida species and their phytochemical analysis 2013;4(2):862-8.

5. Handral HK, SLHoti, SD Shruthi. In vitro evaluation of antimicrobial activities of crude extracts from murraya koenigii against pathogenic bacteria 2012;4(4):74-6.

6. Pandey A, Verma O.P. Nageswaran N. Gupta R. Synergistic antimicrobial activity of edible herns against multi drug resistant bacteria. 2012;7(1):103-5.

7. A.R Prabhakar, Ahuja V. N Basappa. Effect of curry leaves, garlic and tea tree oil on streptococcus mutans and lactobacilli in children clinical and microbiological study 2009;9(3):25963.

8. J.D Sunitha, Patel S, A.S Madhusudan. S.V Ravindra. An in vitro antimicrobial activity of few plant extracts on dental caries microorganisms. 2012;1(3);294-303.

9. S Ajay, S Rahul, G Sumit, M Paras, A Mishra, A Gaurav. Comprehensive review: Murraya koenigii Lnn. Asian Journal of Pharmacy and Life Science 2011;1(4):417-25.

10. Aziman N. Abdullah N. Noor Z.M. Zulkifli S.K. Kamarudin S. Phytochemical constituents and in vitro bioactivity of ethanolic aromatic herb extracts. 2012;41(11):1437-44.

11. Soniya M. Kubersan T.S. Anitha S. Sankareswari P. In vitro antibacterial activity of plant extracts against gram positive and gram negative pathogenic bacteria. 2013;2(1):001-5.

12. Basakaran C, Ratha bai V, Kanimozhi. Screening for antimicrobial activity and phytochemical analysis of various leaf extract of Murraya koenigii. 2011;2(6):1807-10.

13. Vohra K, Gupta VK. Murraya koenigii(Linn) Spreng (Rutaceae) A precious gift from nature. International Journal of Pharma Recent Research. 2011;3(1):18-25.

14. Vandana J. Momim M. Laddha K. Murraya koenigii: An update review. International Journal of Ayuverdic and Herbal Medicine 2012;2(4):607-27.

15. Seniya C, Prakesh B, Bojan D. A precious gift from nature. International Journal of Pharma Recent Research Vol 3 . $2011:$ 18-25

16. Dwivedi D, Patidar KR, Singh V. Antioxidant and antibacterial potential of Murraya koneigii against human cariogenic pathogens. 2012;3(9):3399-406. 